\title{
AMIDOTRIZOATE THERAPY FOR SUDDEN DEAFNESS
}

\section{T. MORIMITSU N. HIRASHIMA K. YASUDA}

\author{
Department of Otorhinolaryngology, Facult of Medicine, Kyushu University. Hamanomachi \\ Hospital Fukuoka
}

Clinical results of amidotrizoate therapy of sudden deafness during the last year were reported. Amidotrizoate used in this:therapy was $76 \%$ Urografin and it was injected intravenously 1-2ml daily. Clinical data and audiograms of 17 cases which showed complete of almost complete recovery were showed in the tables and figures. The interval between onset of deafness and beginning of therapy was on an average 7 days, the longest 43 days and the shortest 3 days. The period during which hearing recovered was on an average for 7 days, most frequent by for 5 days. Three cases with bilateral hearing loss recovered bilaterally, but the pre-existing hearing loss showed no recovery. Clinical data of 15 cases showing no recovery were also reported and discussed. It was noed that the unrecovered cases were those with vertigo, those in which the beginning of theray was lated over 3 weeks and those in which some presumable causes of deafness had been found. In order to comfirm whether or not the new therapy was really effective the rate of recovery of hearing loss was compared with that of Simmons' report and that of our own cases of recoverd completely by another therapy. It was concluded that the amidotrizoate was a specific medicament for the treatment of sudden deafness. From the results obtained, it was prsumed that sudden deafness should be a "barrier break deafness", "endolymph deafness" or "stria vasularis deafness."

A78-0591·23505

\author{
突発難聴のアミドトリゾアート療法

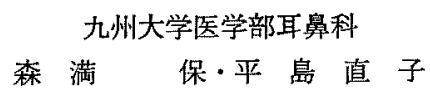 \\ 国家公務員共済組合連合会福岡浜の町病院耳鼻科 \\ 安田宏一
}

\section{緒 言}

突発難㯖は全く健康な人に特に誘因もなく，文字通り 突発的に難聴と耳鳴, ある症例ではこれにめまいを伴な つて発症することで特異的である。その発作は非常に急 激であるために，患者は何月何日，何時何分とその発病 の日時を正確にいえる程である。

このように特異な突発難聴の原因については多くの学 説がある.そしてこの点に関して報告しているほとんど の学者は迷路動脈の血管に障害が生ずるという意見に賛 成している.

しかしながら，現在でもなお，その真の原因は不明で あり，従つて信賴するに足る治療法む確立されていな
W.

1973年 5 月厚生省は乫発難聴, 特にその病因と治療法 の研究を目的とした研究斑を発足させた。

同年9月われわれは造影剤の一種であるアミドトリゾ アート剂が，ある笑発難聴患者の耳鳴と難聴にドラマチ ックに奏効することを発見した1》 それ以来, アミドト リゾアート療法が突発難聴治療の first choice として試 みられ，その特効薬的な効果が確認された．本論文では 1973年9月より1974年8月までの本療法の臨床成績を報 告する。

第一症例

症例1．事務員57才男, No.73-3345 
本症例でアミドトリゾアート䨩の効果が最初に発見さ れた。患者は1973年 8 月 6 日，午前 11 時 30 分頃突発的に 右耳鳴と難聴に気ずいた．次の日に近くの耳番科医を訪 れ，ステロイド剤，ビタミン剂，血管拡張剤などの投与 を5けた。しかしその治療が無効であつたので，8月24 日九大病院耳鼻科に入院した。 8 月24日の聴力検查で は右耳の著明な聴力低下があり，2000 $\mathrm{Hz} ， 4000 \mathrm{~Hz}$ で SISI 值は100\%であつた。左耳にも高音域の高度の損失 が認められ，これは第 2 次大戦中の音響外傷によるもの であるという．カローリックテストを含む前庭機能検查 は全て正常範囲にあつたが，患者は発症当時柽い不安定 感があつたという，全身一般検査，臨床検査成績も同様 に正常範团であった。

患者は連日頸部交感神経ブロックをうけ，また血管拡 張片，ビタミン剂の経口投与をうけた。 2 週間にわたつ て聴力は全く不变であつた，最終的に迷路動脈閉塞が疑 われ椎骨動脈撮影が計画され，9月14日，ヨード過敏症 のテストのために $1 \mathrm{ml}$ のアミドトリゾアート剂が肘静 脈に静注された，20３0分後に，患者は耳鳴が著明に減 少し，次の日には明らかな聴力の改善を訴えた９月19 日聴力検查で法低音域で $15 \sim 20 \mathrm{~dB}$ の回復がみられた. この患者の聴力は発病以来40日間もいろいろの治療に対 して全く反応せず不変であつたことから，この変化は有 意のものと考えられ，さらにアミドトリゾアート投与と の関連性についても検討されたが，日本オージオロジー 学会が定めた有意の聴力変動の判定基準加らもこの変化 は有意のものであると判定された。

アミドトリゾアートの薬理学的な性質を文献的に検討 した結果, 後述するような理由に基づいて本剤を㔖発難 聴の治療に応用してみることが決定された。

\section{完全回復症例の報告}

症例2, 49才男, No. H-73-822

患者は1973年 8 月 22 日，右耳に突然，耳鳴と難聴を生 じたという，次の日耳鼻科に入院した。聴力検查で水平 型50dBの聴力損失を認め, $4000 \mathrm{~Hz}$ は割に良い域值を示 した. (図 1)

左耳にも最高 $30 \mathrm{~dB}$ の楼い聴力損失が認められた。一 般的理学検査, 臨休検査所見は全て正常範囲にあった. ステロイド，ATP 製剤を経口投与され，同時に星状神 経節ブロックを受けた。しかし聴力および耳鳴は43日閒 全く不変であつた。 10月 2 日 $1 \mathrm{ml}$ のアミドトリジアー 卜を始めて静注してみたところ，20分後には図に示され るよ5に，両側に明らかな域值の改善がみられた，10月
6 日, 第 2 回目の静注後の聴力検査では両耳ともに著明 な聴力の改善を示し，10月9日の検査は第 3 回目の注射 後に行なわれたが, 両耳の全周波数における完全回復が 認められ，耳鳴も完全に消失した。

症例3. 主婦52才 No. 72-4035

1973年10月 5 日午後 6 時頃, 急に右耳に耳鳴をきたし た，数日後，電話にかかつて右耳の難聴に気ずいた．め まいやめまい感はなかつた，患者はその他の症状は何も なかつたので，自然回復を期待して 2 週間待つていた が，その期待は裹ぎられた。 10月18日，外来を受診し， その時のオージオグラム（図 1) は右耳の $60 \mathrm{~dB}$ の感音 性損失，水平型を示した，左耳は正常であつた，10月19 日アミトトトリゾアート $1 \mathrm{ml}$ の静注をらけ，翌日，著明 は耳鳴の減弱と聴力の回復を訴えた。10月23日の検查で は右耳の完全回復が認められた。

症例5. 販売員 39才 No. 73-4683

1973年12月 22日, 朝 2 時頃, 急に右耳が闎えなくな り，ついで耳鳴があるのに気づいた，2 日後にある耳鼻 科を訪れ，ステロイト，血管拡張剤，ビタミン剤の投与 をうけた。

12月 27 日，治療効果がはかばかしくないために当科を 紹会された。オージオグラム（図 1）では右耳は 1000 $\sim 4000 \mathrm{~Hz}$ に $70 \mathrm{~dB}$ の損失を示し, 左耳性全く正常であ つた，患者は $1 \mathrm{ml}$ のアドトリゾアート剂の静注をらけ た。 6 時間後に右耳の聴力の著明な改善を自覚し，朝に は不可能であつた電話が聴こえることを知つた。

翌日再び $1 \mathrm{ml}$ の静注をうけ，第 3 日目には左右差がな いよらになつたので受診しなかつたという 1974年1月 22日，始めの耳鼻科クリニックでのオージオグラムは両 側全く正常であった。

これらの症例における劇的な治療効果は突発難聴に対 してアミドトリゾアート療法を続けるのに大きなはげみ となった。

1973年 9 月から1974年8月まで，われわれは17例の完 全，又は略完全治瘾例を得ることができた．これら症例 を一覧表として示し，各々オージオグラムを示す。これ らの症例の臨床経過は大同小異であり, 綝り返しを避け るために省略して，総括的にその特徴を述べることにす る.

年令は19才から71才までで，30 50才台に多く，平均 40才であつた，男女比は $11: 6$ であるが，発病の日時で は季節的な偏りはみられず，時閒的には早朝または起床 時が最む多く 7 例を数える. 患側は右 11 耳, 左 6 耳で右 


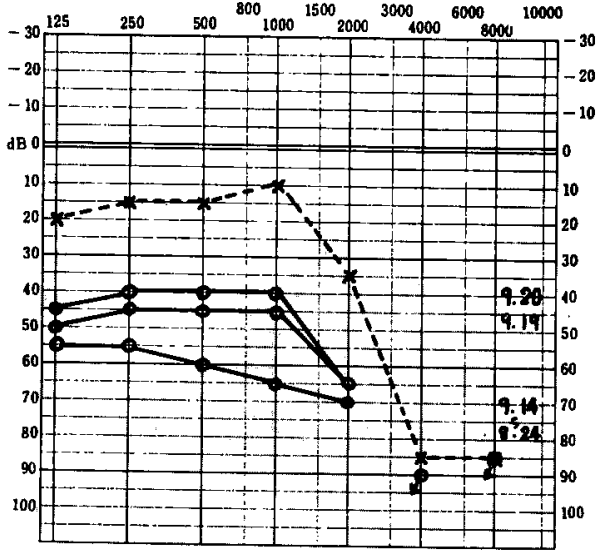

症例1. 森内 57才。

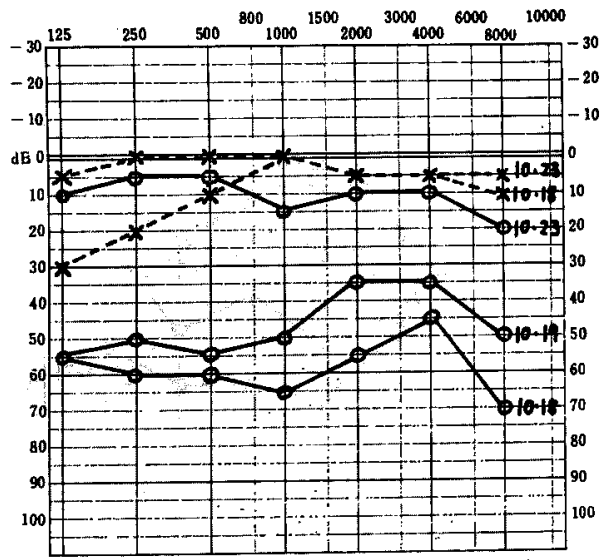

症例.3. 奏 52 才果

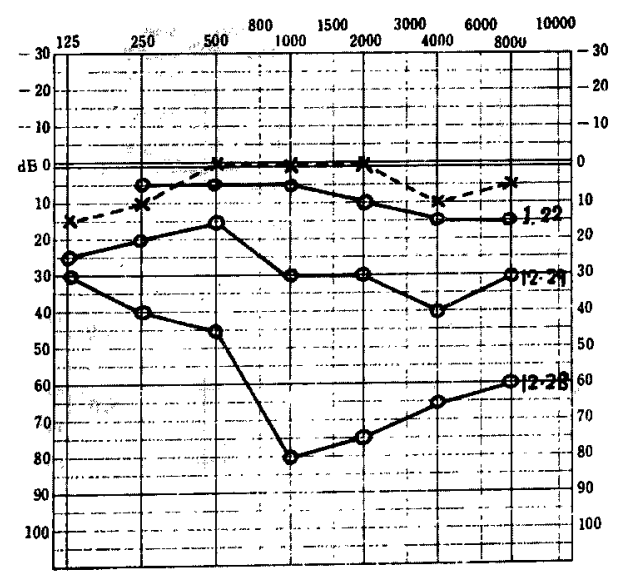

症例5.上田 39才。

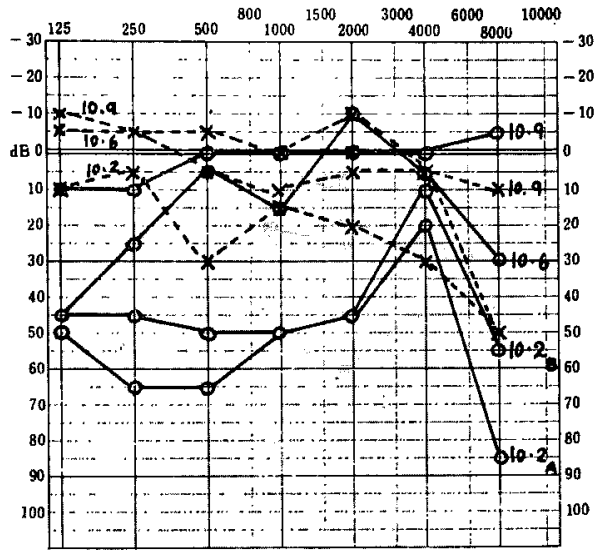

症例2. 田口 49才。

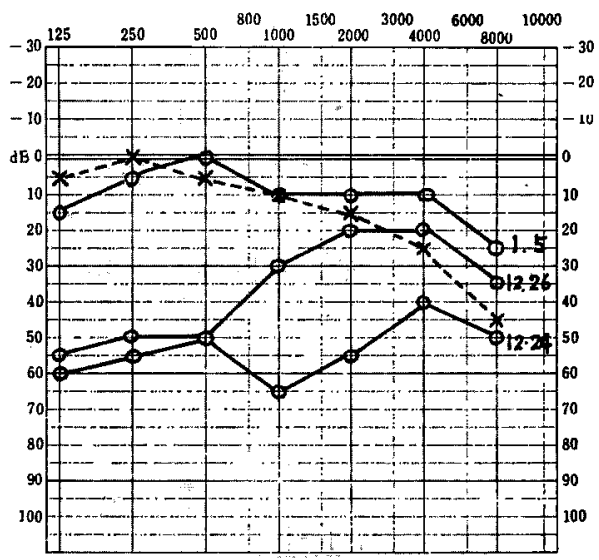

症例4。後藤，50才今

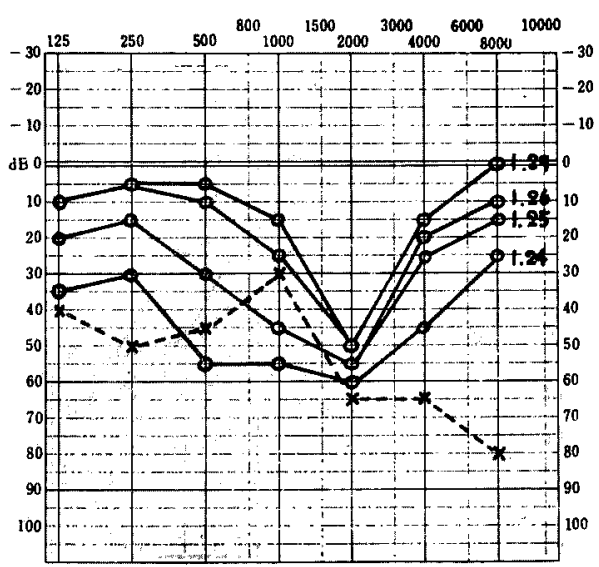

症例6. 古屋 27才우 
図 2
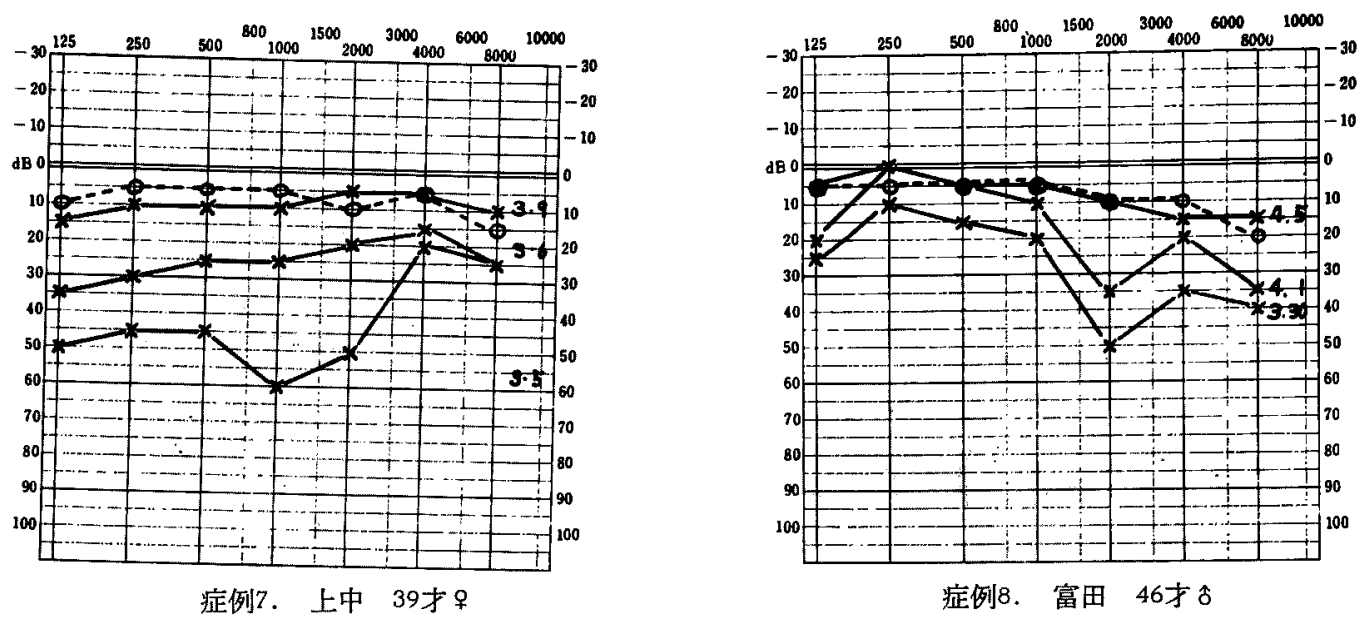

症例8，富田46才。
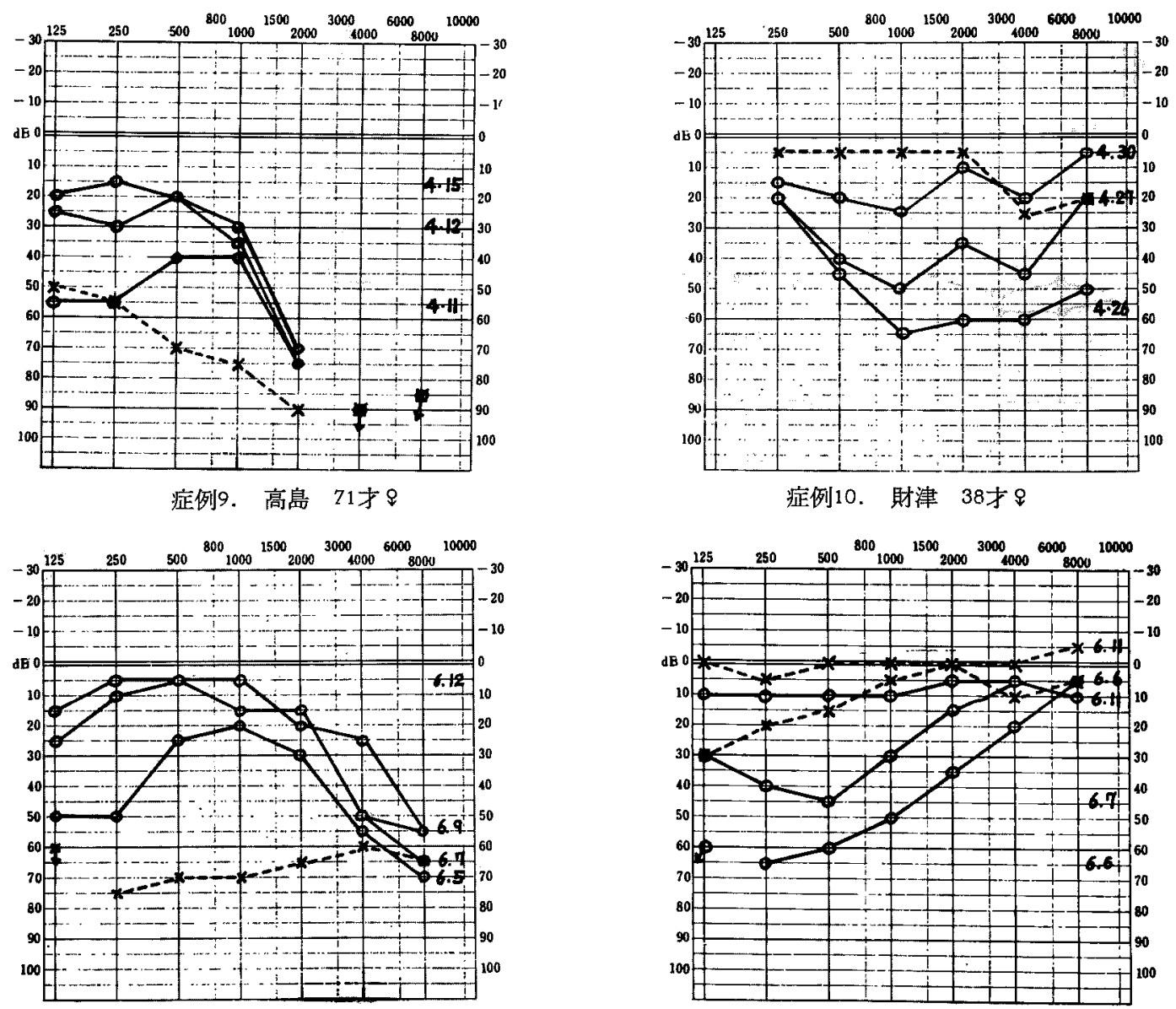

症例11. 清水 37才。

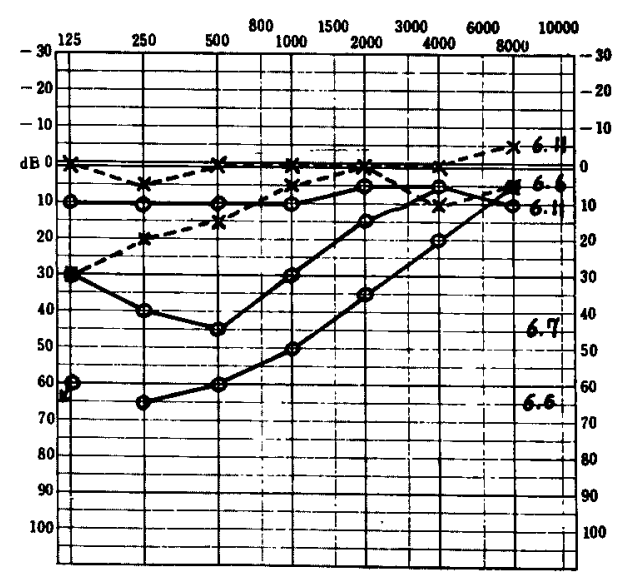

症例 12 荒牧 44 才～ 
図 3

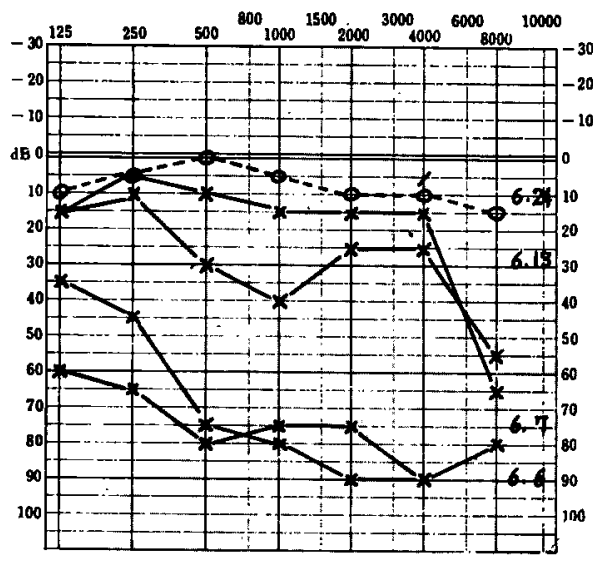

症例 13 斎藤 33 才。

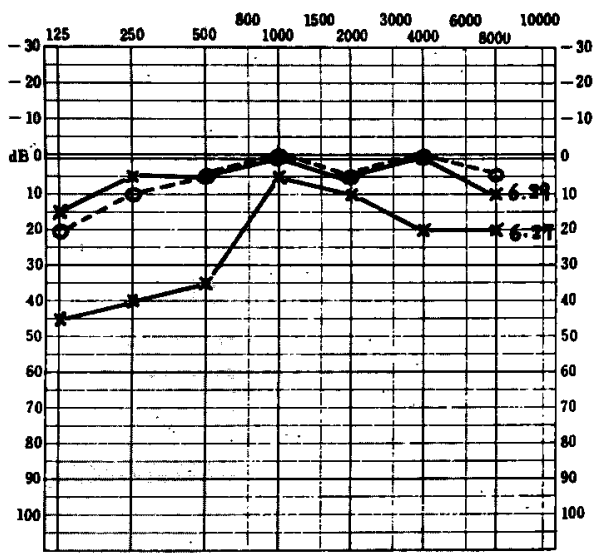

症例15 山田 21 才车

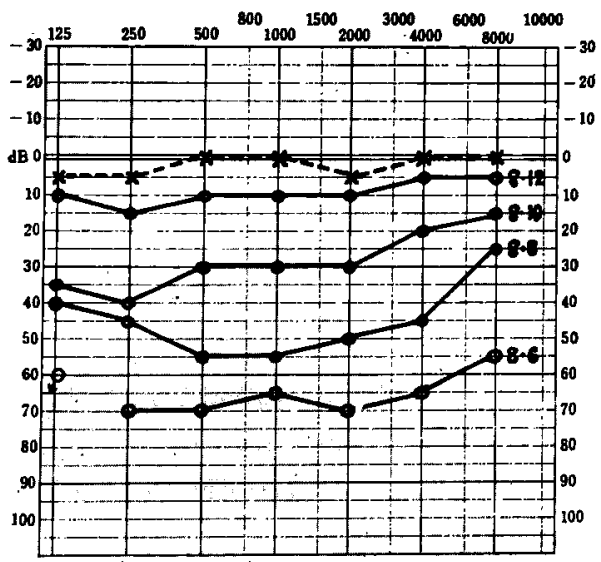

症例17. 三的 33才。

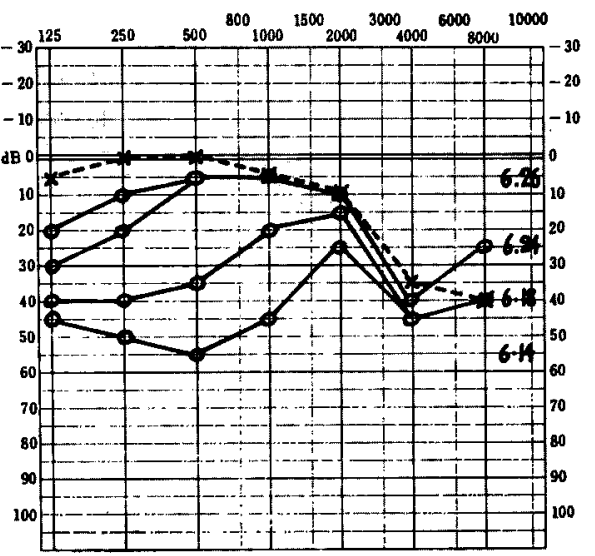

症例14. 春山 32 才。

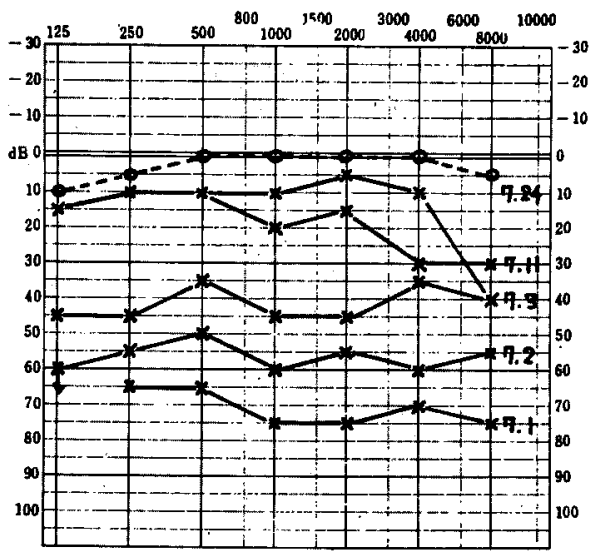

症例16 沢村 19才?

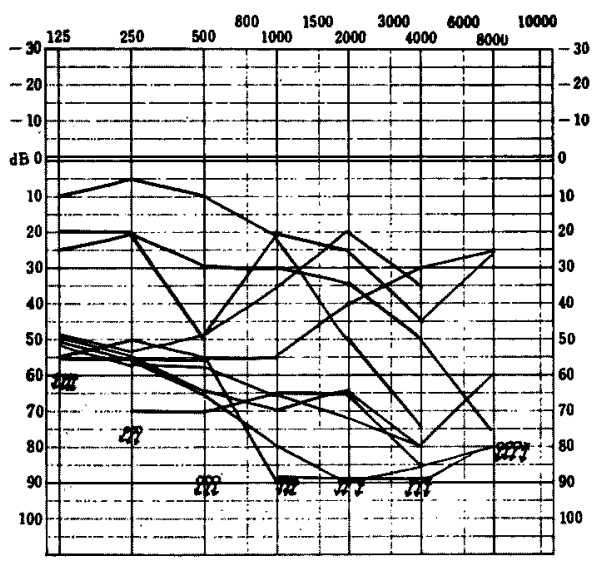

アミドトリゾアート療法無効例の オージオグラム重的合わせ図 
表 1 アミドトリゾアートによる完全回復症例

$1973.9 \sim 1974.8$

\begin{tabular}{|c|c|c|c|c|c|c|c|c|c|c|c|}
\hline No. & 症例 & 命性 & 発 病 日 & 時 & \multicolumn{2}{|c|}{ 患側 - 損失 } & 反対 側 & ·前庭症状 & 治療開女 & 绐・期間 & 回 復 状 況 \\
\hline 1 & 森内 & $57 \hat{\delta}$ & $1973 \cdot 8 \cdot 6$ & $10: 30$ & $\mathrm{R}$ & $65 \mathrm{~dB}$ & high tone loss & dizziness & 40日目 & 7日間 & 部分的 $30 \mathrm{~dB} \uparrow$ \\
\hline 2 & 田口 & 498 & $73 \cdot 8 \cdot 22$ & ? & $\mathrm{R}$ & 85 & 20dB loss & - & 43 & 8 & 両側完全 \\
\hline 3 & 奏 & 52 우 & $73 \cdot 10 \cdot 5$ & $18: 00$ & $\mathrm{R}$ & 60 & 30dB loss & 一 & 15 & 4 & 両側完全 \\
\hline 4 & 後藤 & $50 \hat{8}$ & $73 \cdot 12 \cdot 21$ & 起床時 & $\mathrm{R}$ & 65 & 正 & - & 4 & 5 & 完全 \\
\hline 5 & 上田 & 398 & $73 \cdot 12 \cdot 22$ & $7: 00$ & $\mathbf{R}$ & 80 & 正 & - & 7 & 3 & 完全 \\
\hline 6 & 古屋 & $27 \%$ & $1974 \cdot 1 \cdot 19$ & 起床時 & $\mathrm{R}$ & 60 & S.N. deaf $60 \mathrm{~dB}$ & - & 6 & 6 & 略完企・ $2000 \mathrm{~Hz} \downarrow$ \\
\hline 7 & 上中 & 39 웅 & $74 \cdot 3 \cdot 2$ & $13: 00$ & $\mathbf{L}$ & 60 & 正 & - & 4 & 4 & 完全 \\
\hline 8 & 䔰田 & $46 \hat{0}$ & $74 \cdot 3 \cdot 28$ & 起床㭙 & $\mathrm{L}$ & 50 & 正 & 一 & 3 & 6 & 完全 \\
\hline 9 & 高島 & 718 & $74 \cdot 4 \cdot 19$ & 起床時 & $\mathrm{R}$ & 50 & $\mathrm{~S} \cdot \mathrm{N} \cdot$ deaf $90 \downarrow$ & - & 7 & 5 & 略完全 - 対側不変 \\
\hline 10 & 財津 & $38+$ & $74 \cdot 5 \cdot 29$ & $?$ & $\mathrm{R}$ & 65 & 正 & - & 8 & 5 & 完全 \\
\hline 11 & 清水 & 37 ô & $74 \cdot 5 \cdot 29$ & $7: 00$ & $\mathrm{R}$ & 50 & S.N. deaf & - & 8 & 8 & 略完全·対側不変 \\
\hline 12 & 荒牧 & 44 인 & $74 \cdot 5 \cdot 30$ & $17: 00$ & $\mathrm{R}$ & 65 & $30 \mathrm{~dB}$ loss & - & 8 & 5 & 完全 \\
\hline 13 & 斎藤 & 33 s & $74 \cdot 5 \cdot 31$ & 起床時 & $\mathrm{L}$ & 90 & 正 & - & 7 & 19 & 完全 \\
\hline 14 & 春山 & $32 \hat{\delta}$ & $74 \cdot 6 \cdot 5$ & $22: 00$ & $\mathrm{R}$ & 55 & high tone loss & dizziness & 9 & 13 & 完全 \\
\hline 15 & 山田 & $21 \%$ & $74 \cdot 6 \sqrt{25}$ & $17: 00$ & L & 45 & 正 & - & 3 & 3 & 完全 \\
\hline 16 & 沢村 & $19 \%$ & $74 \cdot 6 \cdot 25$ & 13.00 & $\mathrm{~L}$ & 75 & 正 & - & 7 & 12 & 完全 \\
\hline 17 & 三溒 & $33 \&$ & $74 \cdot 8 \cdot 2$ & $7: 00$ & $\mathrm{~L}$ & 70 & 正 & 一 & 5 & 7 & 完全 \\
\hline
\end{tabular}

側に多、

聴力損失の程度は，その最高損失値または最高改善幅

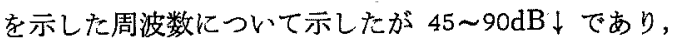
多くは $50 \sim 70 \mathrm{~dB}$ の感音難聴を示した.

反対耳に聴力損失を示寸症例があり，正常耳は 9 例で あつた. 数年, 数十年来の高音域損失を示すもの 5 耳, その中の 1 耳は擎に近いものであつた。

軽度の難聴を示寸むの 3 耳があり，これは聴力検査に 上つて始好て発見されたもので, 低音域20-30dB の損失 であつた。

全例にメニエール病にみる益型的なめまいをきたした ものはなく，僅かに2 例が不安定感を訴えた。この事実 は重要なものと思われる.

アミドトリゾアート療法と発病との間隔を次の項に示 したが，同時に完全回復をでの治療日数も示した，本治 㙩法開始までの期間は最短 3 日，最長43日であり，平均 7 日目であつた。 また治㙩期閒も最短 3 日，最長 19 日 で，平均 7 日間であり，極めて短期間に完全治痖を営ん でいることが分る。

回復状況に関しては，全周波数にわたつて正常となつ たものが大部分であり，部分的な回復を示した 4 例も， 発病前のレベルがそうであつたものと思われるものであ つた.
特笔に值いすることとして，自覚されていなかつた， 検查で始めて発見された反対側の聴力損失も，主病側と 同様に全く正常值になったことがあげられる．

また古くよりあつた難聴 5 耳に対しては，本療法は全 く無勃であつた。

なお，全例で訴えられていた耳鳴は域値の改善ととも に消失した.

\section{無効症例の報告}

上記期間中に突発難聴として診断され，アミドトリゾ アート療法を5け，全く治療効果の認められなかつた15 症例を一覧表として示した．またオージオグラムを重ね 合わせて図示した（図 3）

年令分布，性別，発病の日時，患側などに関しては回 復症例群とほとんど相異は認められない.

患側の聴力状態は，最大損失值が scale out を示寸も のが 5 例あり，その他は 30 80dB で回復群との差は認 められない。

反対側については正常 9 耳, 高音損失 3 耳迷路燚によ る聚一耳, 外傷 1 耳, $\mathrm{C}^{5}$-dip を示すむの 1 耳があつた。

前庭症状に関しては, 回復群との間に極めて対照的な 事実が分つた.すなわち，メニエール病にみる上うな典 型的な回転性めまいを伴なつたもの 7 耳があり，その中 の 5 耳澢力損失も scale out 型であつた。 
表 2 アミドトリゾアート療法艁效症例

\begin{tabular}{|c|c|c|c|c|c|c|c|c|c|c|}
\hline No. & 症例 & 令性 & 発 病 & 日 - 時 & & 側・損失 & 反 対. 側 & \multicolumn{2}{|c|}{ 前庭症状|治療開始 } & その他 - 併用療法 - 合併症 \\
\hline 1 & 柏木 & 62 今 & $1973 \cdot 6 \cdot 24$ & $8: 00$ & $\mathrm{R}$ & scale out & $\mathrm{C}^{5}$ dip. high t.loss & vertigo & 125日目 & S.B $\times 15$. Xylocain \\
\hline 2 & 宮崎 & $56 \%$ & $73 \cdot 7 \cdot 20$ & $15: 00$ & $\mathrm{R}$ & $30 \mathrm{~dB}$ & 正 & 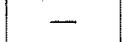 & 97 & $\mathrm{~S} . \mathrm{B} \times 10 . \mathrm{Ni}$ \\
\hline 3 & 迎 & 418 & $73 \cdot 9 \cdot 16$ & ? & $\mathrm{R}$ & 50 & 正 & - & 230 & S.B $\times 15$. Ste \\
\hline 4 & 児島 & $18 \%$ & $73 \cdot 9 \cdot 25$ & $6: 00$ & $\mathrm{R}$ & scale out & 正 & vertigo & 39 & Steroid \\
\hline 5 & 杉 & 52 \& & $73 \cdot 10 \cdot 15$ & $7: 00$ & $\mathrm{R}$ & 75 & total deaf/中耳炎 & vertigo & 29 & S.B $\times 6$. Diabetes mellitus \\
\hline 6 & 石橋 & $55 \hat{8}$ & $73 \cdot 11 \cdot 24$ & 起床時 & $\mathrm{R}$ & 60 & $C^{5}$-dip & - & 109 & Acoustic trauma $(+)$ \\
\hline 7 & 中村 $M$ & $61 \hat{0}$ & $73 \cdot 11 \cdot 25$ & $15 \cdot 30$ & $\mathbf{R}$ & 80 & 外稘 後㹂 & - & 5 & Sensory new \\
\hline 8 & 井手 & 508 & $1974 \cdot 1 \cdot 17$ & ? & $\mathbf{R}$ & 60 & 正 & - & 8 & Industrial su \\
\hline 9 & 中村 $\mathrm{H}$ & 22 웅 & $74 \cdot 1 \cdot 18$ & $6: 00$ & $\mathbf{R}$ & scale out & 正 & vertigo & 5 & S.B $\times 10$. O.H.P.(やや有効) \\
\hline 10 & 小金丸 & 52 令 & $74 \cdot 1 \cdot 30$ & $7: 00$ & $\mathrm{~L}$ & 60 & high tone loss & vertigo & 14 & Meniere suspected \\
\hline 11 & 尾崎 & $57 \delta$ & $74 \cdot 2 \cdot 20$ & $10: 00$ & & scale out & 正 & vertigo & 3 & O.H.P. (無效) \\
\hline 12 & 奥井 & 38 우 & $74 \cdot 2 \cdot 20$ & $8: 00$ & L & 75 & 正 & - & 29 & \\
\hline 13 & 田中 & 29 우 & $74 \cdot 6 \cdot 6$ & $15: 00$ & $R$ & scale out & 正 & vertigo & 14 & S.B $\times 6$, O.H.P.(やや有効) \\
\hline 14 & 吉车田 & 54 우 & $74 \cdot 3 \cdot 18$ & $?$ & $\mathrm{R}$ & 30 & 正 & - & 22 & \\
\hline 15 & 由 & $53 \hat{\delta}$ & $74 \cdot 5 \cdot 20$ & 起床時 & $L$ & 60 & high tone loss & 一 & 45 & \\
\hline
\end{tabular}

治療開始までの期間は最短 3 日目，最長 230 日目であ つたが, 治療期間は平均9日で, 本療法無効として打ち 切られた.

回復状況は全例，何らの改善む認められず，域值に変 動のあつた症例でも，10dB 以内で測定筑差の範囲と思 われた。

最後の欄に併用治療法を示したが，これらの治療法も 同様に無効であり，僅かに高圧酸素療法に反応し 40〜 $50 \mathrm{~dB}$ 損失となつた 2 例があるのみである。
これら非回復例をまとめてみると次のようなことが云 える。

1、めまいのある症例

2. 聴力損失が $90 \mathrm{~dB}$ 以上の scale out 型

3. 治療開始が 3 週間以上遅れた症例

4. 原因と思われるもののある症例，例えば音響外 傷, 糖尿病など.

5.以前よりあつた高度の感音難聴.

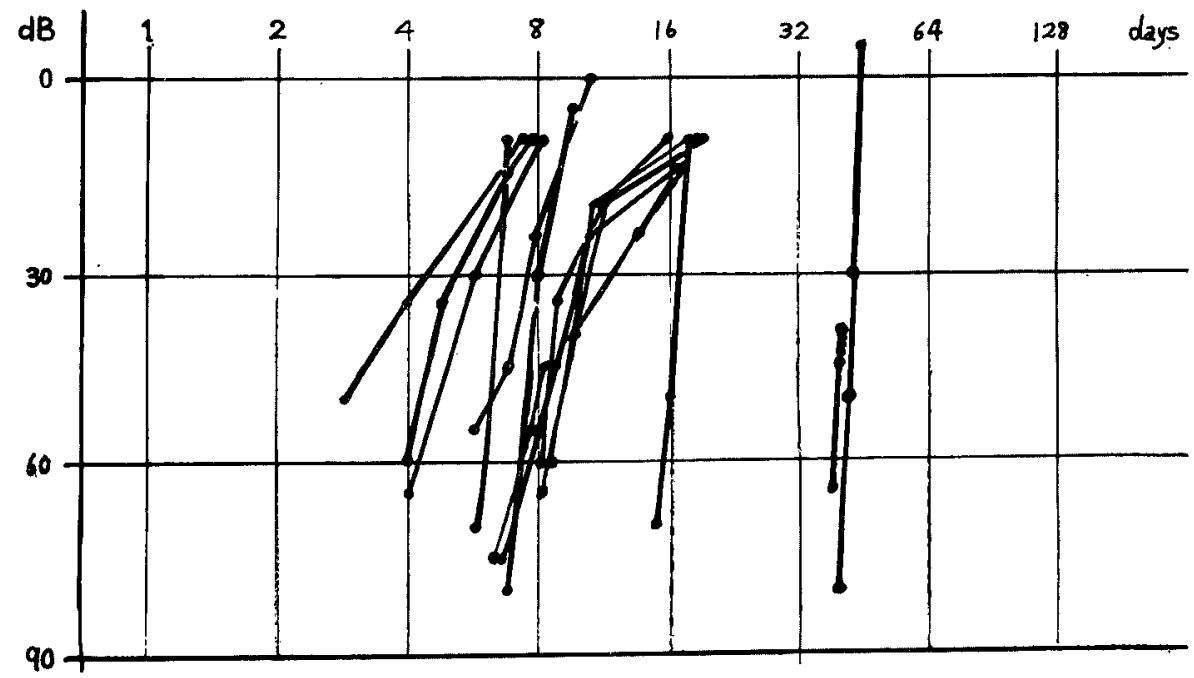

图 4 a. アミドトリゾアート療法による完治例の回復曲線.

最も大巾な回復を示した周波数についての成績 


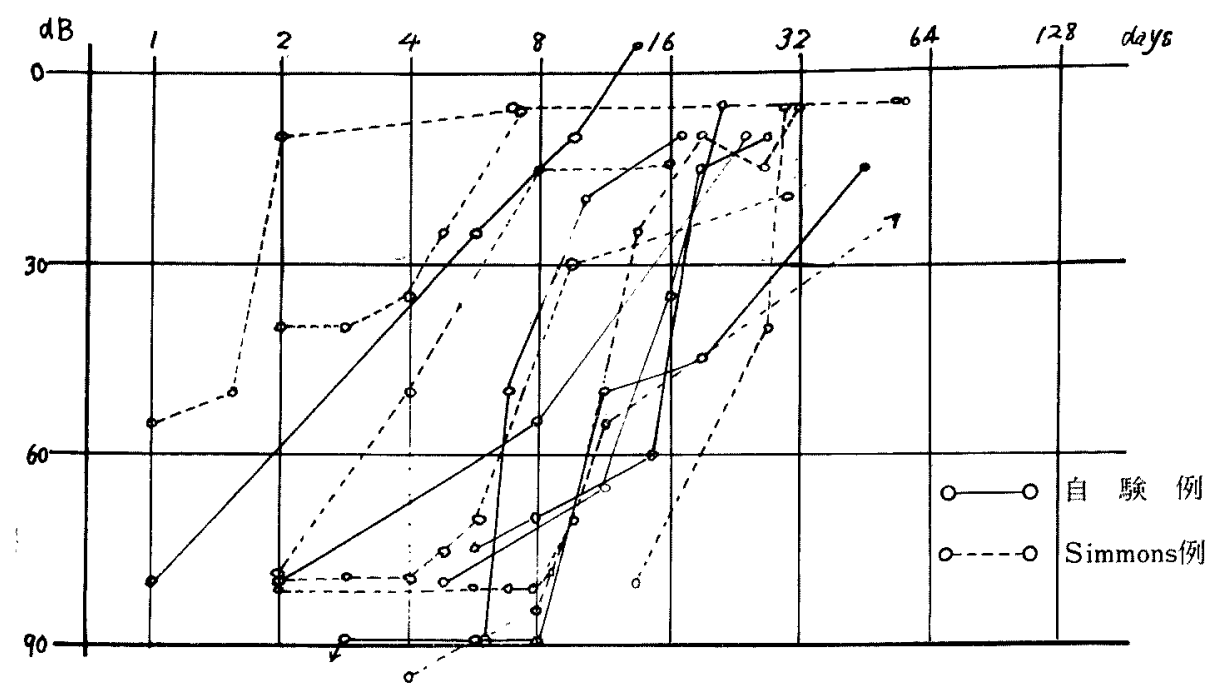

b. 他療法による自験完治例と Simmonsの報告例の回復曲線

\section{考 按}

本報告で用いたアミドトリゾアート剂はその化学式が 3,5-diacetamide-2,4,6,-triiodobenzoate $の \mathrm{Na}$ 塩および meglumine 塩の混合液であるが，76\%ウログラフィン の名で市販されている. 本郕牥これら水溶性のヨード性 造影剂であり静注腎尿路造影や，脳血管造影飞使用され ている.アミドトリゾアートの効果を始めて発見した第 一症例でも椎骨動脈撮影が予定されたためであつた。

本郕が突発難聴に対して実際に有効なのではないかと われわれが推論したのは以下に述べるような理由からで あつた，すなわち，從来，血管条と腎の米球体はその組 織学的な構造や，アミノ配㸵体抗生物質やブロム酸塩2 などの薬物に対する受傷性の点で，相互に類似している といら事実が良く知られている。特に最近はこの両者の 関係はフローセミドやエタクリン酸による難复沈によつ て大きな注目を浴びっつある。

われわれは聴覚電気生理学的な多くの研究の末に，フ ローセミドやエタクリン酸は血管条の Na- ポンプを抑 制し，そのために内リンパを外リンパにかえてしまうこ とを推論した。

アミドトリゾアート棛は腎の系球体毛細管のみから沪 過され尿細管上皮では再吸收されない特別な分子量を持 つている.アミドトリゾアートは第一例では確かに有意 の差をもつて有効であつたので，この薬物は “bload cochlear barrier”を透過することができ，それで 突発 難聴の耳鳴と難聴に好ましい影響を示したのではないか
と推測したのであつた.

1972年 7 月から1974年6月までの間に，われわれは 3 例の全周波数で正常域に回復した突発難聴症例と，低音 域でのみ完全に回復した 3 症例を70例の本症患者の中で 経験している.

一方，われわれはこの一年間で17例の完治またはほぼ 完治症例を経験した。この治療成績の差は有意の差を持 つて明らかであり, 新治療法が, 従来の治療法よりも有 意の差をもって優れていることを示している.

アミドトリゾアート療法が確かに有効な新治療法であ るか否かを確かめる目的で，聴 力の回復度を Simmons の報告例や，主に星状神経節ブロック療法によって正常 レベルにまで回復したわれわれ自身の症例》を対象群と

して比軩してみた。

新療法で治療された症例の結果は第 4 図aに示し，コ ントロール群のそれは第 4. 図bに示した. われわれ自 身の症例は寒線で, Simmons の症例は点線で示されて いる. 図に示されるよらに, 対象群の回復度はアミドト リゾアート療法群のそれに比し明らかに緩やかである. 対象群での治療開始より最後の聴検までの平均日数は 19 日である，突発菶聴の聴力が自然回復または従来の治療 法による回復を示す時には19日閒の間に回復すると考え ることができるよ5に思われる。

アミドトリゾアート療法の平均回復日数は僅かに 7 日 問である.しかも最も頻度の多いのは 4 症例にみられた 5 日間である。このよ5に回復期間が短いことは非常に 


\section{重大である.}

次にアミドトリゾアートの著明な効果は, その回復の 開始が，対象群では治療開始数日後から始まるのに対し て，注射直後からみられるといらことである.

得られた治療成績から，アミドトリゾアート療法は突 発難聴の治療として確かに有効な新らしい療法であると われわれは結論したが，その効果は次のようにまとめる ことができる.

1. 有効であつた症例は常に完全またはほぼ完全回復を 示す いいかえるとその効果は “all or none” 的であ る.

2. 効果の発現は注射直後からである. 耳鳴に対しては 20〜30分以内に，難㯖に対しては 1 日以内に現われ る.

3. 聴力検查に上つて始めて発見された反対耳の聴力損 失む同時に回復する.

4. 回復の速度は極めて速く, 治療の平均日数は 7 日閒 であり，最数値は 5 日間である。

5. 耳鳴は最初に改善を示し，聴力が正常になる時には 完全に消失する.

6. 以前よりあつた聴力損失に対しては，アミドトリゾ アート剤は無効である。

昨年一カ年間にアミドトリゾアート療法および，その 他の療法でも無効であつた突発難聴15例を経験した。 まいを伴なっていた症例は，例えその患者が発病後数日 以内に治療をらけても全例回復を示さなかつた，めまい のある突発難聴とメニエール病を発病直後に鑑別するこ とは非常に困難かまたは不可能なことであるが，アミド トリゾアート療法の成績から，われわれはめまいを伴な 5突発難聴は，伴なわない突発難聴とは別の病気として 区別すべきであろらと考える. 恐らくその病因は異なつ たものであり，あるいはメニエール病の激症型ともいう べきものではないかとも考えられる。

さらにめまいを伴なわない症例でもアミドトリゾアー 卜療法の開始が遅れた症例は全く回復を示さなかつた. われわれの経験では最短22日目であり，最長 230 日目で あつた.この22日目の例は他の治療法を他医でうけ $50 \mathrm{~dB}$ より $30 \mathrm{~dB}$ まで回復した後で来院したものであるが，残 つた $30 \mathrm{~dB}$ に対して無効であつたものである．有効例の 最長期間は 43 日目であるので，突発難聴がアミドトリジ アート療法で回復するか否が 4 〜 週を境いに分けら れるのではないかと推定される。

一般に突発難聴は発病 2 週以内に治療を開始すれば回
復率が高く, 4 週以後にはほとんど回復しないとされて いる. Simmons ${ }^{6)}$ はめまいのない突発難聴は 3 日以内に 受診すれば，68\%は治療が期待され，1 週間目では僅か に11\%に回復が望まれると述べている，3週以後では 0 \%である，われわれの症例ではめまいのない突発難聴は 3 週以内であれば 100\%治療とい5素晴らしいものであ る.

めむいを伴なわない症例でも，無効例の第 8 症例の如 く, 発病の日に川で杭い打ち作業をエアハンマーを使つ て行なつたとか, 第 7 例の如くかなり高度の 難聴があ り, 補聴器を使用していて, 急に難聴が進行した例と か, さらに糖尿病が発見された症例などでは回復がみら れなかつた。 すなわち㔖発難聴の原因が明らかに推定さ れた症例では本療法は無効のようであつた。

一年問の治療成績に基づいてアミドトリゾアート療法 の適応条件を列挙してみると次のよらになる。

1. めまいを伴なわない突発䧼聴

2. 発病後 3 週以内の症例, 但し最長 43 日目の有效例が あるので，2 カ月以内の症例には試みる価値がある.

3. 他に音響など原因と思われるものがない症例.

4. 性別, 年令, 聴力像は無関係である.

最後に，こらした一年間の臨床成續に基づいてアミド トリゾアート剤が何故突発難㯖に有効なのか現時点での われわれの考えを述べてみたい

アミドトリゾアート剤は生体内では何らの化学的変化 もらけず，また蛋白などとも結合することなく血液中に 停まり，投与 2 時間以内にその $95 \%$ 腎の糸球体血管よ り沪過されて尿中に排泄される。僅かに $5 \%$ が肝より睅 汁中に排泄されるが, 血圧, 呼吸, 自律神経その他に何ら の薬理作用も示さないことが知られている。一般に検查 の目的では $20 \mathrm{ml} \sim 80 \mathrm{ml}$ が一気に動注または静注され， 何らの見るべき副作用がないものである．われわれは治 療の目的でせす， $1 \mathrm{ml}$ 次いで $2 \mathrm{ml}$ を肘静脈より静注し た. 本凨は “blood brain barrier”を通過しないことは 承知の通りである。しかし本剂が臨床的に突発難聴に特 効薬的効果を示寸以上, 内耳では当然, „blood cochlear

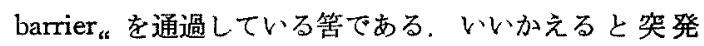
難聴が起ると正常ではアミドトリゾアートを通さない “blood cochlear barrier”が，それを通すよ5な状態に なつているのではないかと推論される. Slood cochlear barrier はフローセミドの難聴からも考えられるように, 盛んに Na- ポンプが作動していて，内リンパより $\mathrm{Na}^{+}$ を汲み出して，高K，低 $\mathrm{Na}$ とい5内リンパ液の組成を 
維持している場である。この blood cochlear barrier の 実在の場は，恐らく血管条の毛細血管と，血管条上皮の 間に存在すると思われるので, barrier を通過したアミ ドトリゾアートの分子はこの部分にとどまるものと思わ れる. 何故ならば血管条上皮は尿細管上皮に類似してお り，尿細管上皮からはアミドトリゾアートは再吸収され ないからである。

結論的に笑発難聴を起した内耳では，アミドトリゾア 一トは blood cochlear barrier を通過するか力，あるいは 頂度その部にとどまつて破糘した barrier を再棈筑する のではないか．そらして Na-ポンプが再び有効に作用 して，正常の内リンパが生産され聴力が改善するのでは ないかといえる。いかえるとアミドトリゾアートは barrier の “pore” の大きさにぴつたり適合する大きさ の分子ではなかららかと思われる. 若しそうであれば突 発難聴はまさに barrier break deafness であり, endolymph deafness であり, また stria vascularis deafness ということができる.

勿論これらは全て推論であつて今後実験的に裹づけら れなければならないことであるが，現時点ではかなり確 からしい推論と考えている.

\section{結 語}

突発難㯖化対し，アミドトリゾアート剤（76\%ウログ ラフィン) がその難聴・耳鳴に有效であることを発見 し，1973年9月より1974年8月まで，アミドトリゾアー 卜療法を first choice とし, 他剤の併用を避けて試みた ところ17例の完治，またはほぼ完治例を得た．また同じ 期間に同療法をうけ全く効果の認められなかつた15例に ついても，有効群と比較検討した，その結果次のような 結論を得た.

1.アミドトリゾアート療法は，めをいを伴なわない 新鮮な突発難㯖に対して特效薬的効果を示す.

2. 平均治療期間は 7 日間, 最頻值は 5 日間とい5警 くぶき短期間に，全周波数で正常範囲に回復を示 す.この治療期間は他の治療法によるそれとは比較 にならない位に短い。

3. 健側耳に発見された軽度聴力損失に対しても有効 で, その効果は両側性である.

4. 回転性めまいを伴なら症例には全く無効である。
回転性めまいを伴なら突発難聴は，伴なわない突発 難聴とは全く別の性格の疾患として区別すべきであ り,これはむしろメニエール病の激症型と考えるべ きである.

5. 治療開始が 3 週間以上遅れるとその治療効果は期 待されにくくなる. 有効例の最長例は43日間である ので一応 2 力月以内の例には試みる価值があるので はないかと考える。

6. 耳鳴は有效例では全例消失した.

以上の劇的な治療効果をもたらすアミドトリソ゚アート 剤の性質から，本療法のメカニズムを検討し，その結果 突発難聴は blood cochlear barrier の破綻による難聴で あり barrier break deafnest, ひいては内リンパの異常 をきたした endolymph deafnessであり，さらにその生 産の場と思われる Stria vascularis deafness ではないか と推論した。

\section{文献}

1) 森満保, 平島直子, 安田宏一：アミドトリソアート が奏効した突発難聴症例。耳奥と臨床，20；599-604, 1974.

2）松元一郎：ブロム酸塩による内耳障害に関する臨床

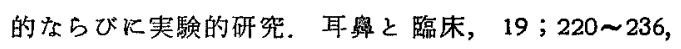
1973.

3) Mathog, P.H. et al: Ototoxity of new and potend diuretics. Arch. Otolaryng. $92 ; 7-15,1970$.

4) F.B. Simmon.: Theory of membrane breaks in Sudden hearing loss. Arch. Otolaryng 88; 67-74, 1968.

5 ) 䈷崎直子, 森満保: 最近 2 年間の突発性難聴症例の 臨床縿計。耳鼻之臨床, $20 ; 6,1974$.

6) F.B. Simmon-: Sudden idiopathic sensori-neural hearing loss: Some observations. Laryngoscope 83 ; 1221-1227, 1973.

本論交の要旨は，第356回九州地方会（1974年 9 月29 日) 及び第16回日本オージオロジ学会・盛岡市 (1974 年10月17日）に拈いて発表した。 又本研究恃厚生省特定 次患突發性難聴調查研究班の矼究費によるるのである。

（原稿受村 昭和49.10.14日） 